\title{
EFFECT OF TREATMENT OF HYPOTHYROIDISM ON CIRCULATORY RESPONSE TO ADRENALINE
}

\author{
BY \\ DAVID LEAK AND MARGIN LEW \\ From the Department of Cardiology, Royal Infirmary, Edinburgh \\ Received April 5, 1962
}

A complex interrelation exists between the sympathetic nervous system and the thyroid gland. High levels of thyroid hormone in animals and man increase the circulatory response to injected catecholamines (Rosenblum, Hahn, and Levine, 1933; Brewster et al., 1956; Goetsch, 1918; Schneckloth, Kurland, and Freedberg, 1953; Murray and Kelly, 1959), and the hyperkinetic circulatory state in hyperthyroidism may be corrected in both animals (Brewster et al., 1956) and man (Gaffney, Braunwald, and Kahler, 1961) by sympathetic blockade. This is accepted as evidence that excess thyroid hormone increases the cardiovascular sensitivity to catecholamines. On the other hand, the evidence that hypothyroidism diminishes the circulatory response to injected catecholamines in the experimental animal and man is less convincing (Rosenblum et al., 1933; Hoffmann, Hoffmann, and Talesnik, 1947; Eppinger and Levine, 1934; Schneckloth et al., 1953).

The response to adrenaline in man may be measured easily by the increase in pulse rate and systolic blood pressure. Recently Raab and his colleagues (Raab, de Paula e. Silva, and Starcheska, 1958; Raab et al., 1960) have used the reduction of the isometric period of the cardiac cycle caused by adrenaline to measure the cardiac sensitivity to adrenaline. Blumberger (1942) described a method of measuring the isometric period indirectly which is convenient to use during intravenous infusions. In the present study changes in pulse rate and the isometric period were used to construct a dose response curve to intravenous adrenaline in hypothyroid patients, before and when receiving treatment with the thyroxine isomers. In addition, the response to endogenous adrenaline secreted during insulin-induced hypoglycæmia was similarly studied during the treatment of hypothyroidism.

\section{MeTHOD}

Carotid arterial pulse tracings low in the neck and a phonocardiogram from the third left interspace near the sternum were recorded simultaneously with standard electrocardiographic leads I or II on a Sanborn Model 62 Twin Beam Cardiette at a paper speed of $100 \mathrm{~mm}$./sec., and were used to calculate the isometric period by Blumberger's (1942) method. Measurements were made with the naked eye. Total systole was measured from the beginning of the $Q$ wave to the first vibration of the second heart sound, and the ejection period from the beginning of the steep ascent of the arterial pulse wave to the dip in the incisura. The isometric period was then calculated by subtracting the length of the ejection period from total systole.

One $\mathrm{ml}$. of 1-adrenaline, 1:1000 solution, was added to $500 \mathrm{ml}$. normal saline and an intravenous infusion set calibrated by the method of Raab et al. (1958) to deliver $0 \cdot 10 \mu \mathrm{g}$. adrenaline $/ \mathrm{kg}$. body weight $/ \mathrm{minute}$. Dose rates of $0.01-0.20 \mu \mathrm{g} . / \mathrm{kg}$. $/$ minute were then derived.

After the patient had rested for 60 to 90 minutes, an intravenous infusion of normal saline was set up and the infusion was allowed to run for 10-15 minutes while the patient settled down. When serial radial pulse and blood-pressure recordings had become steady the isometric period was measured twice at a fiveminute interval. The infusion of adrenaline through the side arm of the saline infusion was then commenced at $0.01-0.02 \mu \mathrm{g} . / \mathrm{kg}$. $/$ minute and the dose increased by small increments to $0 \cdot 10-0 \cdot 20 \mu \mathrm{g} . / \mathrm{kg} . / \mathrm{minute}$. 
At each stage, pulse and blood-pressure readings were taken every minute until stable levels were obtained, and then the isometric period was measured. Similar measurements of the isometric period were made at 15-minute intervals during hypoglycæmia, induced by 0.05 units soluble insulin per $\mathrm{kg}$. body weight.

These experiments were performed on four hypothyroid patients and one euthyroid patient. In three of the hypothyroid patients the studies were carried out before and after treatment with lævo- or dextrothyroxine, and in one after treatment with first the dextro- and later the lævo-isomer of thyroxine.

\section{RESULTS}

The effects of treatment with thyroxine on the protein-bound iodine (PBI), cholesterol, basal metabolic rate, and electrocardiogram in the three untreated patients are presented in Table $I$. Two of the patients became clinically euthyroid, but after six weeks of treatment with $0.3 \mathrm{mg}$.

TABLE I

Effect of Treatment with Thyroxine Isomers in Three Hypothyroid Patients

\begin{tabular}{c|l|c|c|c}
\hline $\begin{array}{c}\text { Patient } \\
\text { No. }\end{array}$ & \multicolumn{1}{|c|}{ Daily medication } & $\begin{array}{c}\text { PBI* } \\
(\mu \mathrm{g} . / 100 \mathrm{ml})\end{array}$ & $\begin{array}{c}\text { Cholesterol } \\
(\mathrm{mg} / / 100 \mathrm{ml})\end{array}$ & T waves \\
\hline 1 & Untreated & $3 \cdot 1$ & 180 & Flat \\
& Dextro-thyroxine 6 mg. & $12 \cdot 0$ & 160 & Upright \\
2 & Six weeks without treatment & $4 \cdot 1 \dagger$ & 315 & Flat \\
& Dextro-thyroxine 12 mg. & $26 \cdot 1$ & 180 & Upright \\
3 & Untreated & $1 \cdot 0$ & 490 & Flat \\
& Lævo-thyroxine 0.3 mg. & $7 \cdot 0$ & 120 & Upright \\
\hline
\end{tabular}

PBI = Protein bound iodine.

* The PBI of patients receiving treatment with dextro-thyroxine is usually high.

$\dagger$ The PBI of this patient before treatment in 1956 was $1.8 \mu \mathrm{g} . / 100 \mathrm{ml}$.

lævo-thyróxine daily patient No. 3 showed a rapid rise of the PBI and fall of serum cholesterol. She became very tolerant of low temperatures, and appeared to be slightly hyperthyroid. The dose response curve to intravenous adrenaline in these three patients is shown in Fig. 1, 2, and 3. In all the patients there was a steady increase in the pulse rate and decrease in the
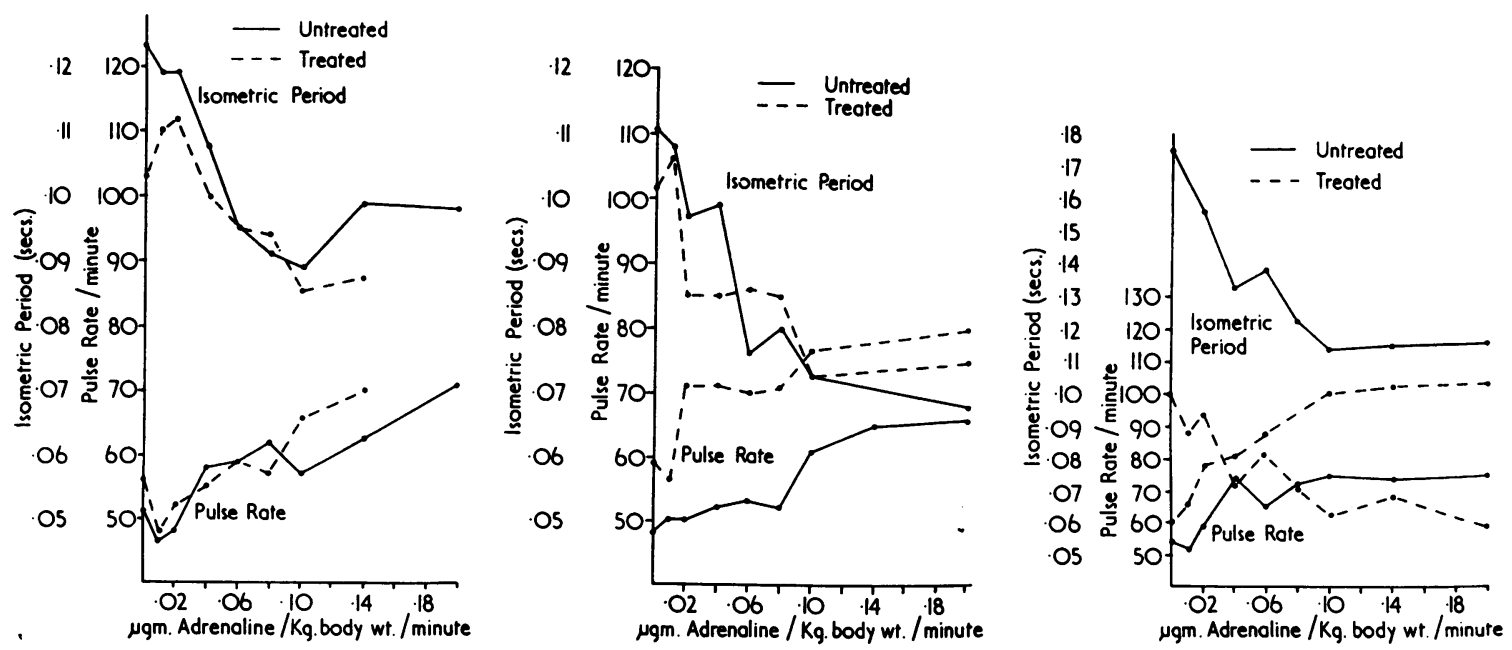

FIG. 1, 2, and 3.-The response of the pulse rate and isometric period to intravenous adrenaline in three hypothyroid patients before and after treatment with thyroxine isomers. 


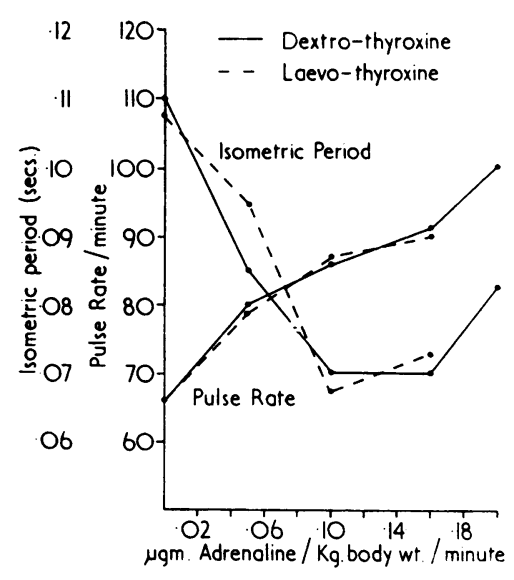

FIG. 4.-A comparision of the response of the pulse rate and isometric period to adrenaline in a hypothyroid patient maintained euthyroid on dextro- and lævo-thyroxine successively.

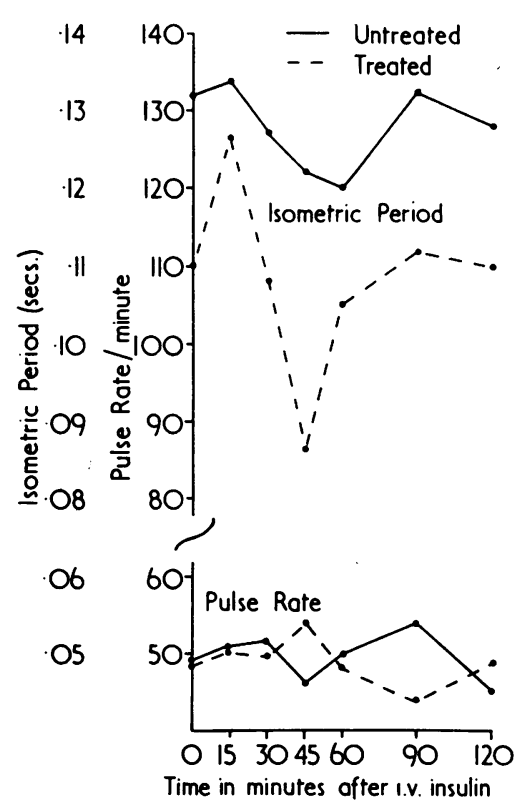

FIG. 5.-The response of the pulse rate and isometric period to insulin-induced hypoglycæmia in a hypothyroid patient, before and after treatment with dextrothyroxine. isometric period as the dose of adrenaline was increased to $0 \cdot 10 \mu \mathrm{g} . / \mathrm{kg}$. body weight $/$ minute, but at a higher dosage the response became very erratic, as counter-regulatory mechanisms came into play. The resting pulse rate of patients No. 1 and No. 3 was almost the same before and after treatment. The increase in pulse rate in response to intravenous adrenaline in patient No. 1 was not affected by treatment, whereas in patients No. 2 and No. 3 it showed a greater increase after treatment. In patients No. 1 and No. 2 therapy scarcely affected the response of the isometric period to adrenaline, whereas in patient No. 3 the isometric period became considerably shorter, although the rate of change was similar.

In one patient with treated hypothyroidism, the dose response to intravenous adrenaline was compared when the patient was maintained at a normal level of metabolism on dextro-thyroxine, and again seven months later when stabilized on lævo-thyroxine (Table II). The pulse rate and isometric period both when resting and in response to intravenous adrenaline were virtually identical during treatment with both thyroxine-isomers (Fig. 4).

The pulse rate and isometric period were measured during an insulin tolerance test in patient No. 1 before and after treatment with sodium dextro-thyroxine. Correction of hypothyroidism appeared to increase the response of the pulse rate and isometric period 45 minutes after insulin injection (Fig. 5).

Finally, the cardiovascular response during insulininduced hypoglycæmia in a euthyroid patient was measured before and after five months' treatment with dextrothyroxine (Table III). The response of the isometric period was virtually unchanged, but the increase in pulse rate was a little greater (Fig. 6).

\section{Discussion}

Schneckloth et al. (1953) reported one patient with myxœdema in whom the response to intravenous noradrenaline was increased during treatment with lævothyroxine, but the dose of nor-adrenaline was not corrected for the weight lost by the patient during treatment; in two other patients, the treatment of congestive cardiac failure with radioactive iodine did not affect the response to noradrenaline after myxœdema had developed, although in one patient the cardiac failure improved. The studies of Eppinger and Levine (1934), which suggested that thyroidectomy reduced the sensitivity to adrenaline, were carried out early in the post-operative period and are therefore difficult to interpret. In this investigation the treatment of hypothyroidism in three patients produced no consistent increase in the response to intravenous adrenaline, as judged by 
TABLE II

Comparison of EfFect of Two Thyroxine Isomers on Patient with Hypothyroidism

\begin{tabular}{c|c|c|c|c|c}
\hline Patient & Daily medication & $\begin{array}{c}\text { PBJ } \\
(\mu \mathrm{g} . / 100 \mathrm{ml} .)\end{array}$ & $\begin{array}{c}\text { Cholesterol } \\
(\mathrm{mg} . / 100 \mathrm{ml} .)\end{array}$ & T waves & $\begin{array}{c}\text { B.M.R. } \\
(\%)\end{array}$ \\
\cline { 1 - 3 } $\begin{array}{c}\text { Man } \\
\text { (46 years) }\end{array}$ & $\begin{array}{c}\text { Dextro-thyroxine 12 mg. } \\
\text { Lævo-thyroxine 0.6 mg. }\end{array}$ & $\begin{array}{r}18.2 \\
6.5\end{array}$ & $\begin{array}{c}330^{*} \\
310^{*}\end{array}$ & $\begin{array}{c}\text { Upright } \\
\text { Upright }\end{array}$ & $\begin{array}{c}-9 \\
-9\end{array}$ \\
\hline
\end{tabular}

* This patient had moderate proteinuria and hypercholesterolæmia as a result of mild nephrosis which was otherwise asymptomatic at the time of the investigation.

TABLE III

Effect of Treatment with Dextro-thyroxine on a Euthyroid Patient

\begin{tabular}{c|l|c|c}
\hline $\begin{array}{c}\text { Patient } \\
\text { No. }\end{array}$ & Daily medication & $\begin{array}{c}\text { PBI } \\
(\mu \mathrm{g} . / 100 \mathrm{ml} .)\end{array}$ & $\begin{array}{c}\text { Cholesterol } \\
(\mathrm{mg} . / 100 \mathrm{ml} .)\end{array}$ \\
\hline 5 & Untreated & $4 \cdot 4$ & 157 \\
& Dextro-thyroxine 8 mg. & $9 \cdot 4$ & 157 \\
\hline
\end{tabular}

measurements of the pulse rate and isometric period. The only significant change in both factors occurred in one patient who was probably treated to the stage of hyperthyroidism.

The increased cardiovascular response during insulininduced hypoglycæmia after treatment with dextrothyroxine in one previously hypothyroid patient was probably due to the increased release of adrenaline from the adrenal medulla, which accompanies the correction of hypothyroidism, as has previously been demonstrated in this patient (Leak and Brunjes, 1962).

Cannon, McIver, and Bliss (1924) showed that the cardiovascular response to insulin-induced hypoglycæmia was not abolished by adrenalectomy. It is therefore interesting that treatment of a euthyroid patient with dextro-thyroxine did not change the circulatory response to hypoglycæmia for it has been shown earlier in this patient and several others, that a high circulating thyroid hormone level may block the adrenal medullary response to hypoglycæmia (Leak and Brunjes, 1962).

Boyd and Oliver (1960) showed that dextro-thyroxine may have a less stimulating effect on the myocardium than

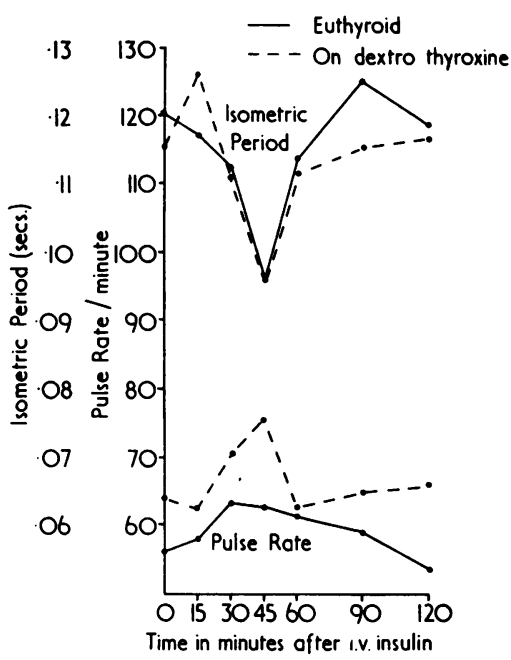

Fig. 6.-The response of the pulse rate and isometric period to insulin-induced hypoglycæmia in a euthyroid patient before and after treatment with dextrothyroxine. lævo-thyroxine, while retaining an equivalent ability to reduce the serum cholesterol, and it has been suggested that this is due to a lack of synergism in the myocardium between dextro-thyroxine and adrenaline (Starr, 1961). In this experiment, however, there was no significant difference in the response to intravenous adrenaline in a patient maintained euthyroid on the dextro- and lævo-isomers of thyroxine in succession.

It seems reasonable to conclude that hypothyroidism may not always reduce the cardiovascular sensitivity to adrenaline in man, although the circulatory response in certain circumstances, such as insulin-induced hypoglycæmia, may be diminished as a result of a reduction in endogenous adrenaline released from the adrenal medulla. The undoubted synergism between thyroid hormone and the catecholamines may, in fact, only exist at abnormally high levels of thyroid hormone activity. 


\section{SUMMARY}

The response of the pulse rate and isometric period of cardiac contraction to graded doses of intravenous adrenaline was determined in three hypothyroid patients before and after treatment with the thyroxine isomers. Treatment did not appear to increase the cardiovascular sensitivity to adrenaline except in one patient treated to the stage of hyperthyroidism, suggesting that the synergism between thyroid hormone and the catecholamines may exist only at abnormally high levels of thyroid hormone activity. The response to intravenous adrenaline was similar in a patient when maintained euthyroid by dextro- and by lævo-thyroxin- in succession. The circulatory response to insulininduced hypoglycæmia was increased by the correction of hypothyroidism, probably as a result of increased adrenaline secretion from the adrenal medulla.

This work was carried out in the Department of Medicine, University of Southern California School of Medicine, Los Angeles, California.

\section{REFERENCES}

Blumberger, K. (1942). Ergebn. inn. Med. Kinderheilk., 62, 424.

Brewster, W. R., Isaacs, J. P., Osgood, P. F., and King, T. L. (1956). Circulation, $13,1$.

Boyd, G. S., and Oliver, M. F. (1960). Brit. med. Bull., 16, 138.

Cannon, W. B., McIver, M. A., and Bliss, S. W. (1924). Amer. J. Physiol., 69, 46.

Eppinger, E. C., and Levine, S. A. (1934). Proc. Soc. exp. Biol. (N. Y.), 31, 485.

Gaffney, T. E., Braunwald, E., and Kahler, R. L. (1961). New Engl. J. Med., 265, 16.

Goetsch, E. (1918). N.Y. St. J. Med., 18, 259.

Hoffmann, F., Hoffmann, E. J., and Talesnik, J. (1947). Amer. J. Physiol., 148, 689.

Leak, D., and Brunjes, S. (1962). Lancet, 1, 863.

Murray, J. F., and Kelly, J. J. (1959). Ann. intern. Med., 51, 309.

Raab, W., De Paula e. Silva, P., Marchet, H., Kimura, E., and Starcheska, Y. K. (1960). Amer. J. Cardiol., 5, 300.

,-- , and Starcheska, Y. K. (1958). Cardiologia (Basel), 33, 350.

Rosenblum, H., Hahn, R. G., and Levine, S. A. (1933). Arch. intern. Med., 51, 279.

Schneckloth, R. E., Kurland, G. S., and Freedberg, A. S. (1953). Metabolism, 2, 546.

Starr, P. (1961). Acta endocr. (Kbh.), 37, 110. 